DOI: 10.21005/pif.2021.46.C-04

\title{
WIND RESOURCES IN THE URBAN STRUCTURE - CFD NUMERICAL ANALYSIS. POSSIBILITIES OF USING WIND ENERGY ONTHE EXAMPLE OF THE SŁONECZNE ESTATE IN SZCZECIN
}

\section{ZASOBY WIETRZNE W STRUKTURZE MIEJSKIEJ - ANALIZA NUMERYCZNA CFD. MOŻLIWOŚCI WYKORZYSTANIA ENERGII WIATRU NA PRZYKŁADZIE OSIEDLA SŁONECZNEGO W SZCZECINIE}

\section{Rafał Obuchowicz}

Eng. architect

Author's Orcid number: 0000-0003-4138-236X

West Pomeranian University of Technology, Szczecin

Faculty of Architecture

\begin{abstract}
The issue of wind in an urbanized structure, considered in the context of benefits, forces to undertake activities across multiple disciplines. The lack of understanding of the aerodynamic phenomena in heterogeneous space may lead to failures in implemented projects. The article presents the general scope of issues related to the urban wind turbine and the numerical CFD simulation of air flows in the Słoneczne housing estate in Szczecin, together with the conclusions drawn from it.
\end{abstract}

Key words: CFD, city, renewable energy sources, wind turbine.

\section{STRESZCZENIE}

Problematyka wiatru w strukturze zurbanizowanej, rozpatrywana w kontekście korzyści, zmusza do podejmowania działań z zakresu wielu dyscyplin. Brak zrozumienia zjawisk aerodynamicznych w przestrzeni niejednorodnej prowadzić może do niepowodzeń w realizowanych projektach. W artykule przedstawiono ogólny zakres zagadnień związanych z wiatrowymi turbinami miejskimi UWT oraz symulację numeryczną CFD przepływów powietrza na szczecińskim osiedlu mieszkaniowym Słoneczne, wraz z płynącymi z niej wnioskami.

Słowa kluczowe: CFD, miasto, odnawialne źródła energii, turbina wiatrowa. 


\section{INTRODUCTION}

The policy of the ever more restrictive climate regulations that have been introduced in the world in recent years, in particular those covering the countries of the European Union, successive thresholds for reducing greenhouse gas emissions and ever shorter deadlines for achieving them make the problem of obtaining energy from renewable sources be considered important in places where it has been neglected so far. Wind resources, used in non-urbanized areas, in the urban environment are not taken into account, or used to a small extent. Wind-related phenomena in the city, often associated with discomfort, are rarely considered in terms of benefit, such as city ventilation corridor systems or a renewable energy source. These factors lead to the view of wind as an energy source that is constantly present in the urban fabric and ready to be used.

From a historical point of view, the methods of wind energy conversion can be divided into several periods defined by qualitative changes in technology. We find traces of the first conscious use of wind for energy purposes about five thousand years ago in the Mediterranean region (Leather T. M. 2017, p. 130), where it was used to propel boats. The structure of the units allowed to decompose the wind force vector into a useful component allowing to steer the boat along a marked course and a parasitic component causing undesirable drift. Another change, the documented traces of which have survived to this day, took place in the areas of ancient Persia in the 7th century BC. (Leather T. M. 2017, p. 131). It uses mechanics derived from the sail shell, mounting it on a rotating structure that allows stationary operation. The functioning of a turbine constructed in this way has not changed to the present day, and modern constructions, with the exception of a few experimental devices, work on the same principle. The transformations which structures have undergone over the centuries concerned mainly technology and brought significant quantitative changes to the efficiency of energy machines. The Charles Brush device, built in 1888 in Cleveland, Ohio, can be considered the first wind turbine constructed using the principles of a systematized scientific approach (Fig. 1). The $12 \mathrm{~kW}$ generator was fully automatic, it had a wind overload steering and protection system, an intermediate gear with a generator, current regulation and batteries (Lynn P. A. 2017, p. 13). All these elements are involved in contemporary constructions.

\subsection{Purpose of the article}

The main aim of the research was to check the possibility of using wind machines in built-up space.

\subsection{Conducted research}

The presence of wind machines, which in the past was a frequent element of the settlement system, generates the need to analyze the possibilities and purposefulness of their modern use. The energy aspect, as obvious and intuitively accepted, becomes more than one in the urban structure. The aerodynamics of the housing estate as the test area is also considered in terms of the comfort of users, and a strong wind is considered an undesirable phenomenon. The installations of small wind turbines considered in this context, by taking over some of the wind energy, become not only devices generating electricity, but also consciously designed, they can serve to control and shape mesoclimatic conditions. From the point of view of fluid mechanics, a wind installation, in a simplified manner, can be treated as a porous structure that slows down the flow, and if it is properly located, similarly to trees, it influences the local wind conditions. On the other hand, the high requirements of turbines as regards the work environment are connected with the necessity of high specialization of the design process and knowledge of aerodynamic phenomena occurring in the urban environment.

The wind conditions in the built-up zone diametrically differ from those in the open space. Due to terrain obstacles, they are distinguished by a large variation in wind speed and the presence of numerous turbulent flows. Turbines operating in installations must meet a number of stringent conditions, in particular, be characterized by low speeds: starting and for nominal power, have a short reaction time and high fatigue resistance. The most common criterion for the division of wind generators used in urbanized areas is the position of the rotor axis of rotation, according to which we distinguish two types of devices: 
- with a horizontal axis of rotation - Horizontal Axis Wind Turbines (HAWT),

- with a vertical axis of rotation - Vertical Axis Wind Turbines (VAWT).

Fig. 1. Charles Brush Dynamo in Cleveland. (Renewable Energy)

Ryc. 1. Dynamo Charles'a Brush'a w Cleveland. (Renewable Energy)

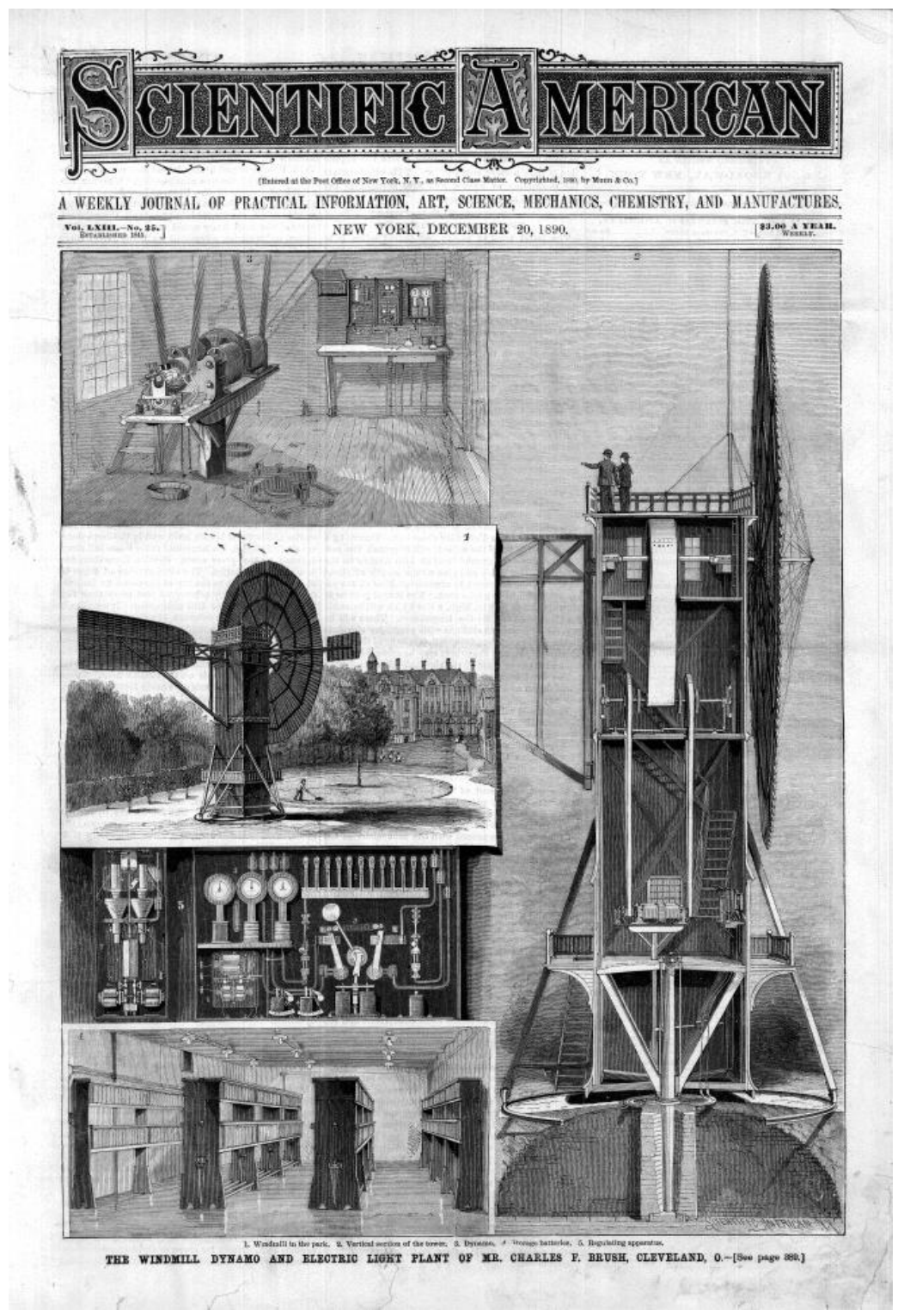

This division, despite its obvious advantages, does not reflect the entire problem and is too limited to the assessment of the usefulness of devices operating in an urban environment. The typification introduced by Abohela, which defines the degree of integration of the wind device with the development or local spatial system, is more adequate (Abohela I. 2012, pp. 83-94). According to this classification, we distinguish four systems:

- Building Integrated Wind Turbines (BIWT) - stand-alone wind turbines operating close to buildings and taking advantage of the increase in wind velocity due to the surrounding buildings. Often installed in existing buildings or incorporated into new urban projects. This type of integra- 
tion in a built environment is typically implemented where there are open spaces such as squares, sports fields.

- Building Mounted Wind Turbines (BMWT) - structures directly mounted on the building as their basis and used to increase the wind energy going to the turbine. They are used both in the design of wind systems on existing and newly built buildings, most often installed on the roof, less often on the edges. Integrations implemented in this way do not affect the functional layout of the building.

- Building Augmented Wind Turbines (BAWT) - this type of integration subordinates the building architecture to maximize the efficiency of the wind installation. The aerodynamic shape of the structure is used to provide concentrated wind energy to drive the turbine. In such projects, the architect plays a major role in shaping the body of the building based on aerodynamic aspects. Comprehensive knowledge of wind energy concentration and conversion systems is required from him. Projects in line with this approach are particularly effective. The best known are: SE1 loss (Fig. 2) in London, Bahrain World Trade Center, or Pearl River Tower in China.

- Ducted Wind Turbines (DWT) - type of built-up turbines operating in a specially designed channel. Used where there is a large pressure difference at the ends of the channel. The shape of the inlet and outlet play an important role, as well as spoilers that help to concentrate the energy obtained from the wind. In the case of too high flow velocities inside the channel, shutters are activated to protect the turbine against damage. These installations, apart from energy conversion, can be used to support the building's ventilation system.

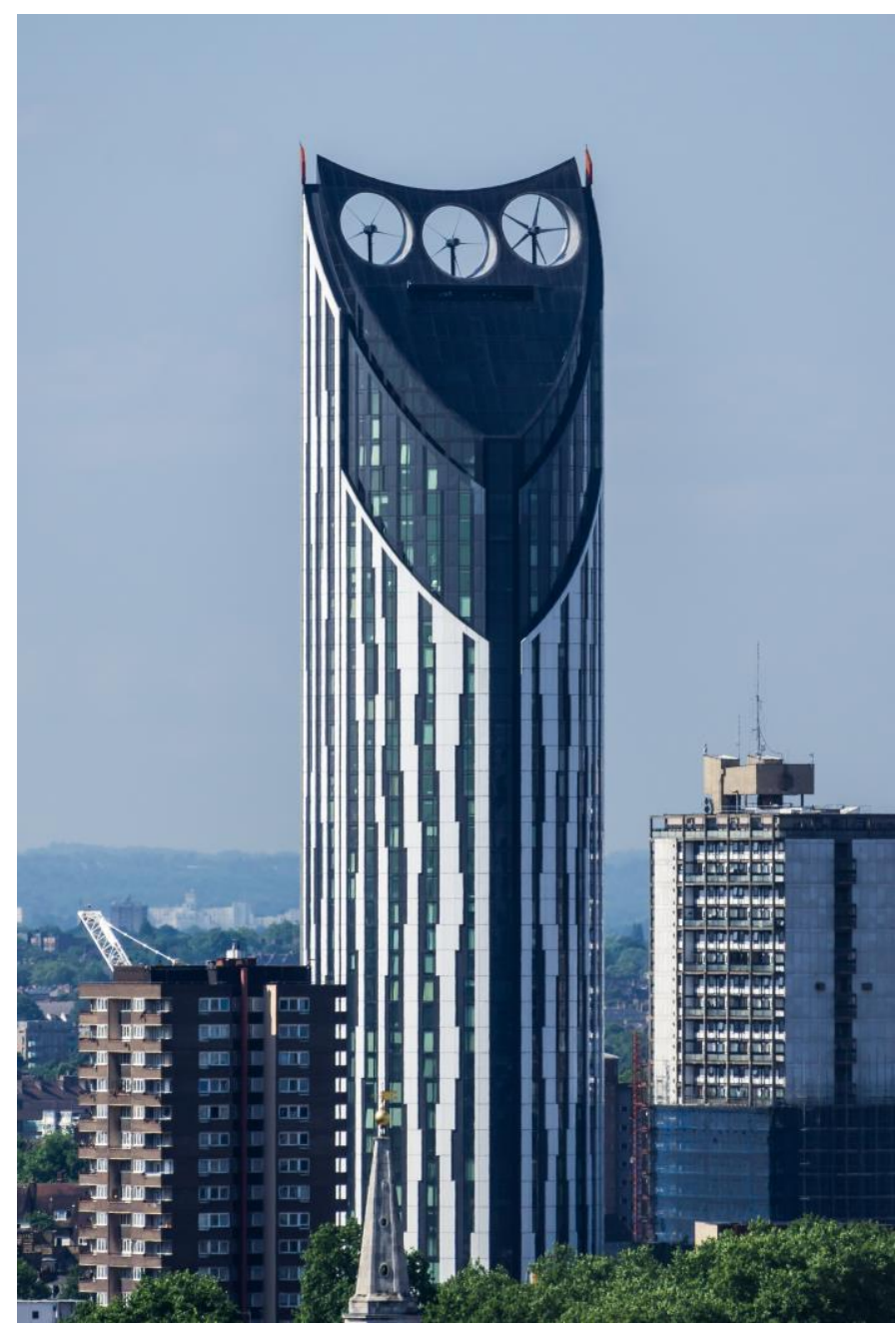

Fig. 2. Strata SE1, London. (Wikimedia Commons)

Ryc. 2. Strata SE1, Londyn. (Wikimedia Commons) 
Interpretation of wind conditions in isolation from the above-mentioned design approaches leads to erroneous conclusions and is the cause of frequent failures of undertaken projects. Effective use of wind energy in an urbanized environment requires taking into account many factors that do not exist in open areas for turbines operating in a free air stream.

\section{CHOICE OF THE RESEARCH AREA, METHODOLOGY}

The choice of the object was limited to Szczecin buildings. In the first phase, eight groups with features favoring the occurrence of useful wind phenomena were selected. Then the object for numerical analysis was selected from among this group.

The analysis of the geometric structure of the urban layout in terms of favorable conditions for wind farms indicated high-rise housing estates. These are housing complexes mostly composed of highrise buildings, XI - XIII. storeys and complementing their urban layout of buildings with the height of the IV - V storeys. These estates, made in the reinforced concrete prefabricates technology, were built in Szczecin in the 70s, 80s and 90s of the last century. The problem of high wind, considered in this study as a phenomenon that may bring benefits under certain conditions, has been dealt with from the very beginning of the emergence and settlement of the discussed settlements. The authors of the studies pay attention to undesirable phenomena related to the local microclimate, such as troublesome drafts between buildings (Wojtkun G. 2014, p. 80), very strong winds, or turbulences referred to by residents as whirlwinds (Wojtkun G. 2014 , p. 105). The initial selection selected eight Szczecin estates with similar spatial conditions, height stratification and the technology in which they were created. Housing estates Arkońskie, Bandurskiego, Bukowe, Kaliny, Książąt Pomorskich, Majowe, Słoneczne and Zawadzkiego, despite the common features of building morphology such as height, cubature of buildings and their proportions, show significant differences in aerodynamic characteristics resulting mainly from the spatial arrangement of buildings, orientation in the field, number and distribution of open zones within the considered assumptions. The distances between individual units and the angles of their elevation planes in certain places favor local acceleration of air mass flows, while in others they create dead zones, free from wind.

The aforementioned estates were assessed in terms of the features determining the occurrence of aero-dynamic phenomena that may be considered as favorable or excluding the functioning of wind micro-installations in the environment of a residential complex. On the other hand, the subject of interest was the possibility of limiting unfavorable phenomena, such as excessive local acceleration of air masses, wind blows resulting from the occurring turbulence, which can be leveled by means of wind installations absorbing the kinetic energy of the wind and dampening the flows in critical places.

The introduced evaluation criteria assume a division into a global (macro) system, which is the entire housing estate, and a local (micro) system, where individual elements such as buildings and their mutual relations, narrowings, shades, openings, etc. are taken into account. - varying the height and plan of the estate into the general aerodynamic characteristics determining the possibility of free air flow, where parallel structures like long streets with relatively compact buildings allow local winds to move smoothly (wind-permeable system). It is disturbed by closed building systems ("impermeable" to the wind), forming polygons or closed loops (...) causing the air to stop and swirl (Zielonko-Jung K. 2013, p. 45). Considering the phenomena acting locally, several patterns were distinguished describing the behavior of the wind in the urban environment depending on the geometry of the building development and its mutual relations (Flaga A. 2008, p. 333). The following have been distinguished here: the bar effect - this is the case in the case of medium-high buildings with a length of at least eight times greater than the height. The phenomenon arises when the wind direction forms an angle close to $45^{\circ}$ with the building axis. As a result, most of the air masses around the building flows over it and descends on the leeward side, causing an increase in the stream velocity and numerous swirls. The flow constriction effect also known as the venturi effect - arises in the case of two buildings whose wall planes form an acute angle with each other, and the wind direction is close to the bisector of this angle. The height of the planes must be at least five stories high, and the sum of their lengths must not be less than $100 \mathrm{~m}$. The phenomenon 
arises when the width of the outlet is two to three times smaller than the inlet and is characterized by significant wind accelerations in the outlet zone. The gap effect - a phenomenon characteristic of housing estates, where a long building collides with a communication route, for which a communication passage is created on the ground floor, the gate or building is supported on poles. With the wind perpendicular to the facade and the building height of five or more storeys in the opening strip, the air masses accelerate significantly due to the large pressure difference between the windward and downward sides of the building, and the effect intensifies with increasing building height. The phenomenon is quite common and perceived as unfavorable due to the discomfort of residents. Corner effect - is related to the formation of a pressure difference around the corners of buildings, resulting from the pressure of air masses from the windward side and suction from the leeward side, resulting in a zone with increased wind speed. The disturbance is closely related to the height of the building. It begins to play a significant role in buildings over five storeys, and it becomes a particular problem for high-rise buildings. The effect of swirls in the aerodynamic wake - the wind lines, after meeting the building, merge only at a certain distance behind it, creating an aerodynamic shadow zone with reduced static pressure on the leeward side. Due to the existing pressure differences, this phenomenon can be considered as particularly advantageous for wind installations integrated with the building. The channel effect - sometimes called the suction effect, occurs in the case of parallel systems, e.g. a street with dense strings of buildings on both sides and the height of buildings three times greater than the width of the street. The system creates a channel for the air stream and creates anomalies in combination with e.g. strong turbulence. The downwash vortex effect - is created in the case of buildings with a significant difference in height, adjacent to each other at a short distance, approximating to the height of the lower building. The axes of the buildings are mutually parallel and the wind direction is perpendicular to them. Behind the windward, lower building, a turbulence area of the flowing air is created, and in the corner zones of the tall building there are significant increases in wind speed. The screening effect, also known as the shelter effect, inverts the pattern of the whirling down effect, with an obstacle of greater height on the windward side. The lower object remains in the aerodynamic shadow of the higher one in the zone of turbulence and lowered pressure. We deal with such a situation in the case of shading by tall buildings, road screens, green belts. The aforementioned aerodynamic patterns, occurring simultaneously, can create complex relationships, multiplying or eliminating each other.

When making the selection between the settlements, apart from the occurrence of conditions potentially favorable for wind installations, the aerodynamic and spatial differentiation of the structure allowing for demonstrating the complexity and correlation between the described aerodynamic phenomena was taken into account. For numerical analysis, computational fluid dynamics (CFD), the buildings of the Słoneczne housing estate in Szczecin were selected (Fig. 3). It is an estate with the greatest wind potential. The height differentiation and development plan indicate the possibility of numerous accelerations and damming of the wind line. The buildings are dominated by: from the west - windward side, the central layout, consisting of three high, thirteen-storey buildings on a three-pointed star plan, surrounded by an almost closed circle formed by five-storey buildings, and a linear layout, consisting of two thirteen-storey buildings from the leeward side. High buildings with free spaces generate very different flows. Numerous aerodynamic shadows creating large pressure differences and the presence of gates cause local increases in flow velocity, useful due to the possibility of using wind energy sources.

The map of the local wind conditions of the estate was made with the use of CFD modeling, included in the calculation methods of wind engineering. The simulation of conditions in the building model shows the fluctuations in the velocity of air masses, and the vertical component of the wind speed $\mathrm{Vz}$, distinguished on the next map. The qualitative assessment of the flow allows the identification of areas of acceleration, damming up and stagnation, on the basis of which the occurrence of potentially favorable zones for the location of wind installations can be estimated. 


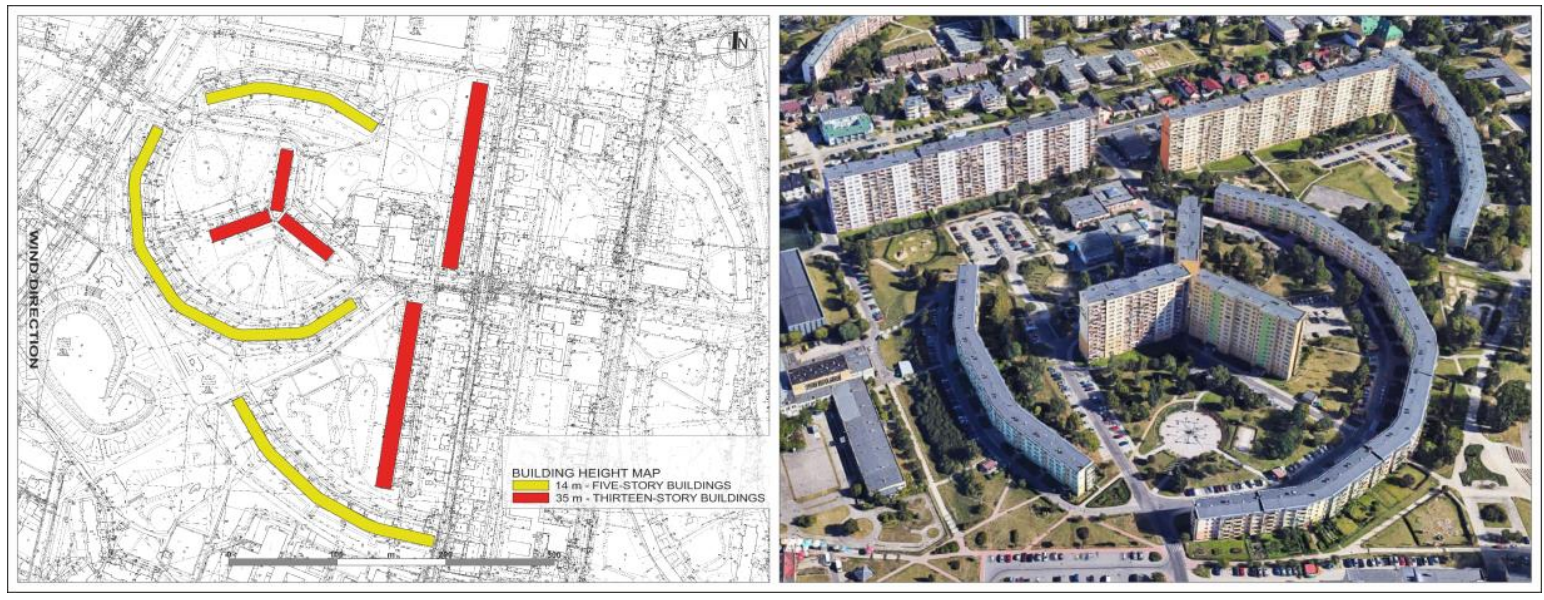

Fig. 3. plan and view of the Słoneczne estate in Szczecin. Source: geodezja UM Szczecin, Google street-view, prepared by: author

Ryc. 3. Rzut i widok osiedla Słoneczne w Szczecinie. Źródło: geodezja UM Szczecin, Google street-view, opracowanie: autor

\section{AIR FLOW RESEARCH}

The conducted study is qualitative in nature. Its purpose was to indicate places with increased values of air flow velocity and areas of stagnation (zones of silence). The most common wind direction for a given area is adopted. The values were marked as relative to the average wind speed in the studied area and were presented as a percentage scale. In the morphology of buildings, three groups of objects characterized by the consistency of features essential for generating characteristic aerodynamic phenomena were distinguished. These are: group I of three tall buildings - thirteenstorey on the plan of an isosceles star, II - a complex of two parallel thirteen-storey buildings with slightly shifted axes, forming a wall 390 meters long with a gap in the middle, and complex III, which consists of buildings medium-high, five-storey, forming segments of circles on the projection. The areas that were assessed had to meet the criteria of the technical possibility of installing wind generators in the existing development and the presence of favorable wind conditions (Fig. 4).

The general relationships that were observed for the entire development complex are the decrease in the velocity of air masses inside the modeled system combined with its increase at the extreme points; increase in wind speed with increasing height above ground level; and a greater tendency to change the direction of air movements in low layers. The greatest differentiation of wind conditions occurs in the lowest studied cross-section, 5 meters above the ground. There are five zones of increased flow and three areas of strong turbulence on it. The buildings of complex III play an important role in shaping the flow at this height. The incoming air, depending on the angle created in a given place with the facade running in a circle, picks up in front of the building, creating the effect of a flowing vortex behind it, or flows around it, creating the effect of an elongated barrier. The constrictions created by the buildings of complexes II and III are responsible for the Venturi effect and rapid wind acceleration. Complexes I and III form two zones of local acceleration, and due to the irregular development plan, the phenomena generated by them show a high complexity. The buildings of complex II, with a total length of 390 meters and a height of 35 meters, create a compact, almost perpendicular $\left(81^{\circ}\right)$ obstacle for the incoming air. The small gap between the buildings is a place of strong acceleration of the air masses due to the pressure difference upstream and downstream of the obstacle. The stream acceleration zone marked there, due to the complexity of the geometry (eccentric shift of the building axes) and the intensity of the occurring aerodynamic phenomena, has the highest energy potential for wind installations in a given area. In the case of the upper parts of thirteen-story buildings in complex I and II, in the edge areas of their walls and roofs, the simulation showed local accelerations caused by the corner effect. The zones for renewable energy sources were also marked there (Fig. 5). 


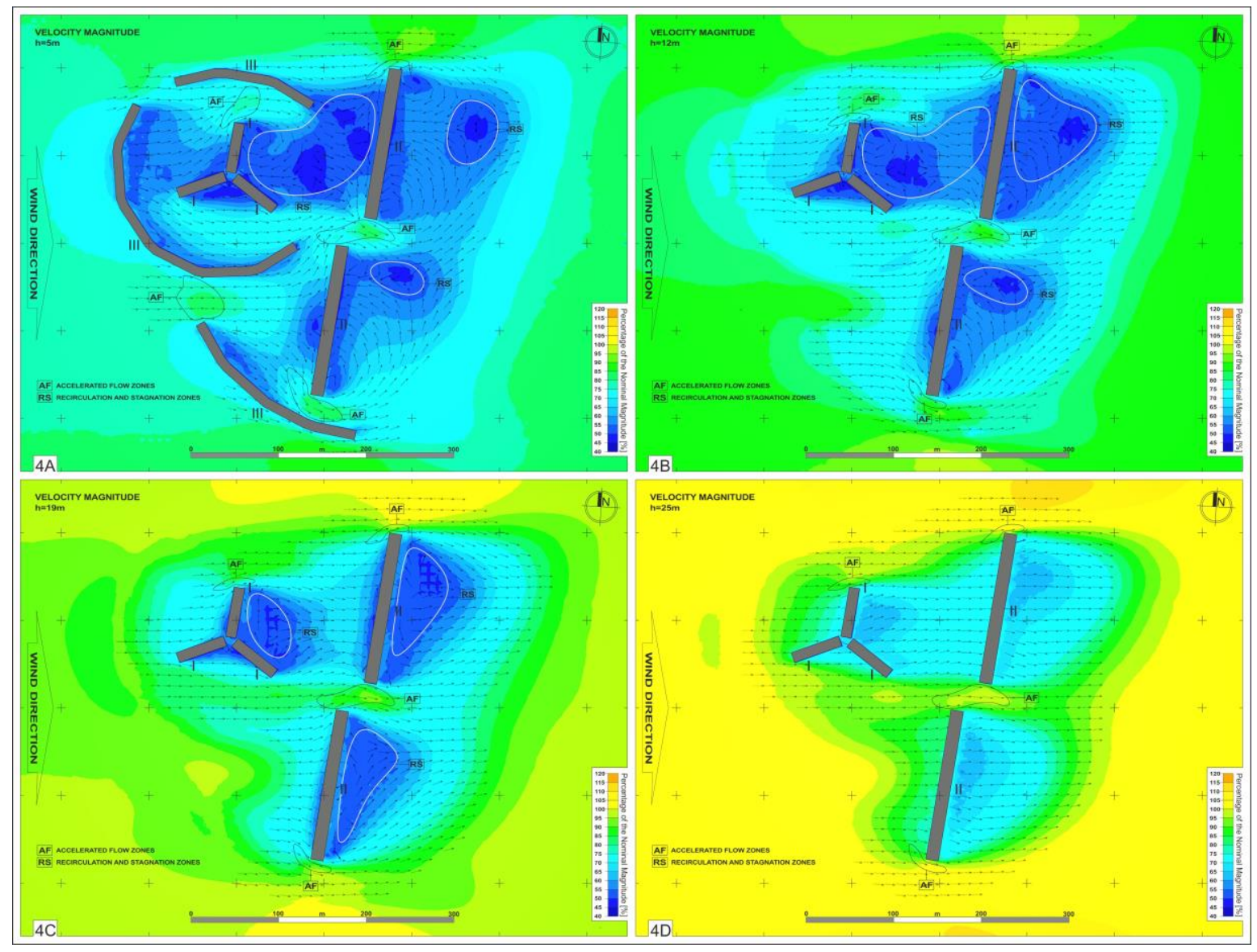

Fig. 4. CFD simulation of the flow velocity in the tested model. The areas marked with colors assume air velocity values within the ranges described on the scale. The value of $100 \%$ corresponds to the nominal wind speed. Source: author

Ryc. 4. Symulacja CFD prędkości przepływu w badanym modelu. Obszary oznaczone barwami przyjmują wartości prędkości powietrza z zakresów opisanych na skali. Wartość $100 \%$ odpowiada nominalnej prędkości wiatru. Żródło: autor

An important aspect of the study was the separation of the vertical component from the vector of air mass velocity $(\mathrm{Vz})$, visualized on the charts. This element in urbanized conditions plays a significant role, and its omission leads to numerous failures in the implemented installations. The zones of increased vertical movements can be observed mainly in the adjacent areas of buildings and at a considerable distance behind complex II. It is caused by the damming of the wind lines throughout the entire development and sucking it through the area of lowered pressure behind the housing estate - the effect of turbulence in the aerodynamic shadow. We observe a similar situation on a smaller scale, analyzing individual buildings separately. In the case of high, thirteen-storey buildings, the air that meets the building on its way, up to about one third of its height, takes a negative $V z$ value, creating a recirculation zone in the low parts of the building, while above this height it goes up, obtaining the highest vertical velocity in the gable parts, having a significant participation in shaping the aerodynamic characteristics of the roof. The range of the influence of vertical movements should be assumed as considerable. This is illustrated by the impact of group III in layer 5D, the height of which above the ground level is more than twice the height of the buildings causing the phenomenon. The isolation and analysis of the $\mathrm{Vz}$ component should be considered a necessary condition when assessing the windiness of the system under study, as it shows how important the vertical component is in an urbanized area. 


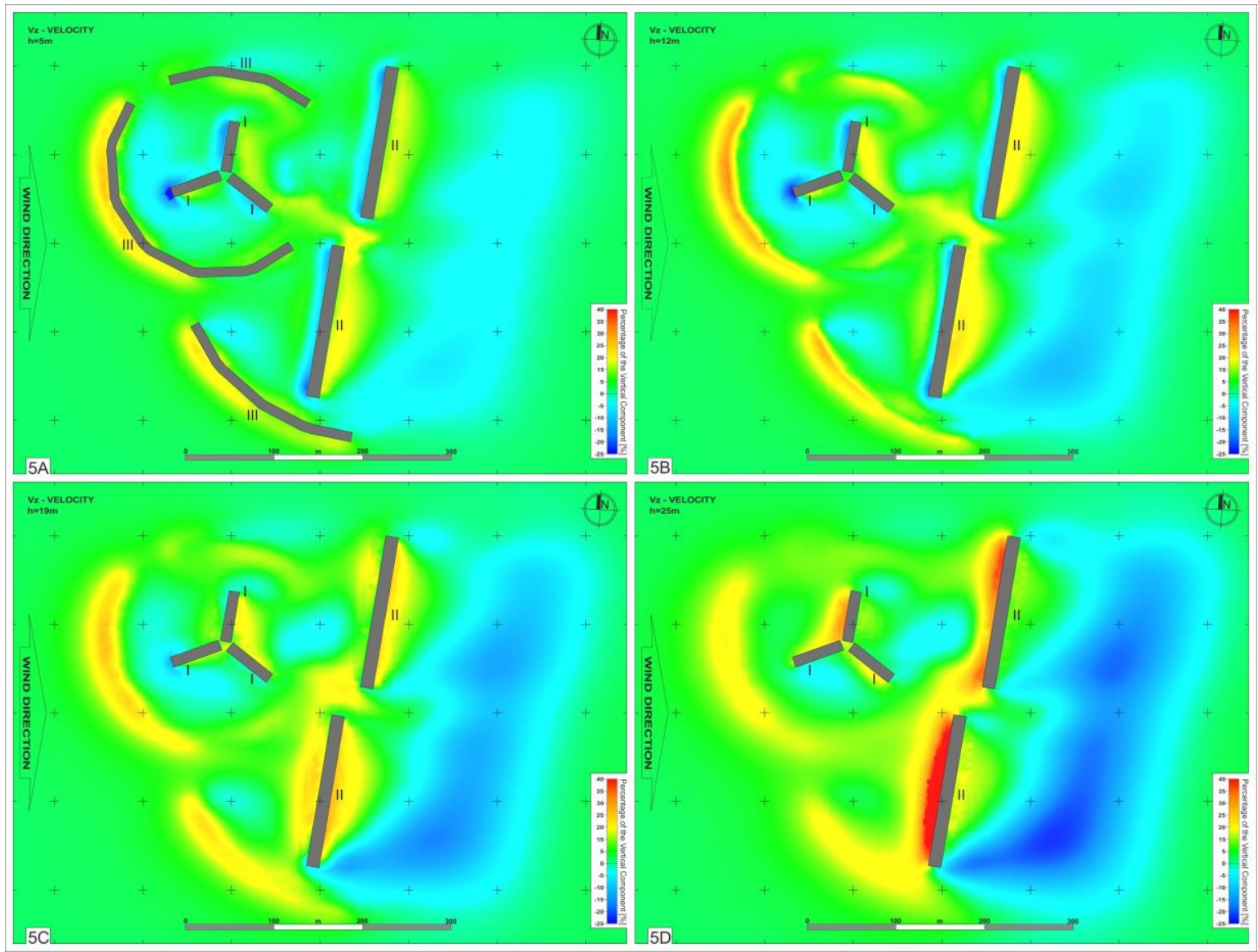

Fig. 5. CFD simulation, vertical component of the flow velocity Vz. Designation on a gradient color scale - values according to the scale in the drawing. Source: author

Ryc. 5. Symulacja CFD, składowa pionowa prędkości przepływu Vz. Oznaczenie w skali barwowej gradientowej - wartości wg skali na rysunku. Źródło: autor

Analyzes and description of wind phenomena in the Słoneczne estate in Szczecin, prepared with the use of analytical methods, are presented in the monograph Housing estate in the structure of the city of the 20th century by G. Wojtkun (Wojtkun G. 2014, p. 76). Numerical modeling fully confirmed the above-mentioned research and supplemented it with a vertical element.

\section{DISCUSSION}

Wind conditions in a built-up environment differ significantly from those in an unimpeded flow environment, such as an open field, where the wind pattern can be considered almost two-dimensional. The turbulent nature of the wind field occurring in urbanized areas introduces the vertical element as the third component of its speed, affecting the wind installation operating in urban conditions (Anup K. C. et al, 2018, p. 5). In addition to the complexity of wind phenomena, their unpredictability and stochastic nature are indicated that cannot be described by any known statistical distribution (Zielonko-Jung K. 2013, p. 60), as well as an insufficient number of detailed field tests and measurements that would help characterize the wind urban and understand its impact on turbines (Anup $\mathrm{KC}$ et al, 2018, p. 6). Despite these obstacles, the authors show a number of benefits resulting from the use of urban wind installations, including those going beyond wind energy conversion, and 
cover a number of issues related to the improvement of the quality of the area's functioning. The most important include:

- Change in the characteristics of the windy space towards calming down, slowing down the occurring drafts and gusts of wind. A wind turbine is a turbulating element and reduces the energy of the air stream passing through it. The useful power generated in the wind turbine, taken from the air stream, results from the difference in the kinetic energy of the air in front of and behind the rotor. This is particularly advantageous in places where there has previously been trouble with too much wind activity.

- The use of wind installations for integration with systems supporting the use of buildings, in particular the use of wind for natural ventilation (Zielonko-Jung K. 2013, p. 72).

- With the increasing capacity to use wind resources in urban areas, small wind turbines (SWT) intended for operation in an urban environment and turbines integrated with buildings are of value for architects and designers due to the fact that the input coefficient of non-renewable primary energy in the calculations is zero. energy performance of buildings, giving greater freedom in designing installations.

- Renewable energy wind farms are an excellent tool that provides enormous amounts of data on the current conditions, useful for creating weather maps, forecasts, and managing "smart city" systems.

- Diversification of energy sources, dispersion of the energy system, omitting transmission losses.

- Short implementation time of wind installations (Leather T. M. 2017, p. 8).

- The social aspect, currently indicated as particularly important, brings image benefits for the region, local community and individual. Green buildings influence perception; a modern architectural object becomes a sign of a place using (...) the latest technologies (Czekiel-Świtalska E. 2008, p.1), a positive identifier on the scale of the estate, district, city.

In the context of the expected profits, the fulfillment of high requirements can be considered justified. At the same time, assuming the complex conditions necessary to be met when designing urban wind turbine (UWT) installations (Anup K. C. et al, 2018, p. 2). Faced with the environmental problems that we are currently struggling with, we must be aware that the problem of using wind in the urban environment will have to be taken up, and that it is a forward-looking trend that requires development (Zielonko-Jung K. 2013, pp. 77- 78).

\section{CONCLUSIONS}

The use of wind turbines in an urbanized environment requires an understanding of wind conditions and its aerodynamic phenomena. Failures of attempts to use wind energy result from the fact that devices not adapted to this are installed. Urban wind turbines operate in radically different conditions from their commercial counterparts in the open or at sea, and their similarity is apparent. Flows formed by obstacles have a very complex dynamics, which means that shaping the form of the immediate vicinity of the turbine should be treated in a special way. The complexity of design issues requires the cooperation of designers from various specializations.

The diagram describes the scheme of cooperation between design industries and defines the domains that belong to the area of their activities. In addition to the architect / town planner, who determines the main design assumptions and the conditions in which the installation will operate, specialists in the field of construction and operation of machines, materials engineering, fatigue and strength issues, energy and automation as well as aerodynamics play an important role. Their cooperation should take place in all phases of the project.

Another problem is the indication of places favorable in terms of windiness for turbines in the development. In the tested model, it is only $5.5 \%$ of its projected area. This fact illustrates how important it is to analyze the flows in the system and how easy it is to make a mistake in determining the location for the generators. Therefore, the numerical analysis of flows should be considered a minimum requirement in the initial design phase. This approach will avoid mistakes and 
use the layout not as an obstacle, but as an element shaping the wind lines in a way favorable to the installation. Providing optimal working conditions and guaranteeing maximum efficiency.

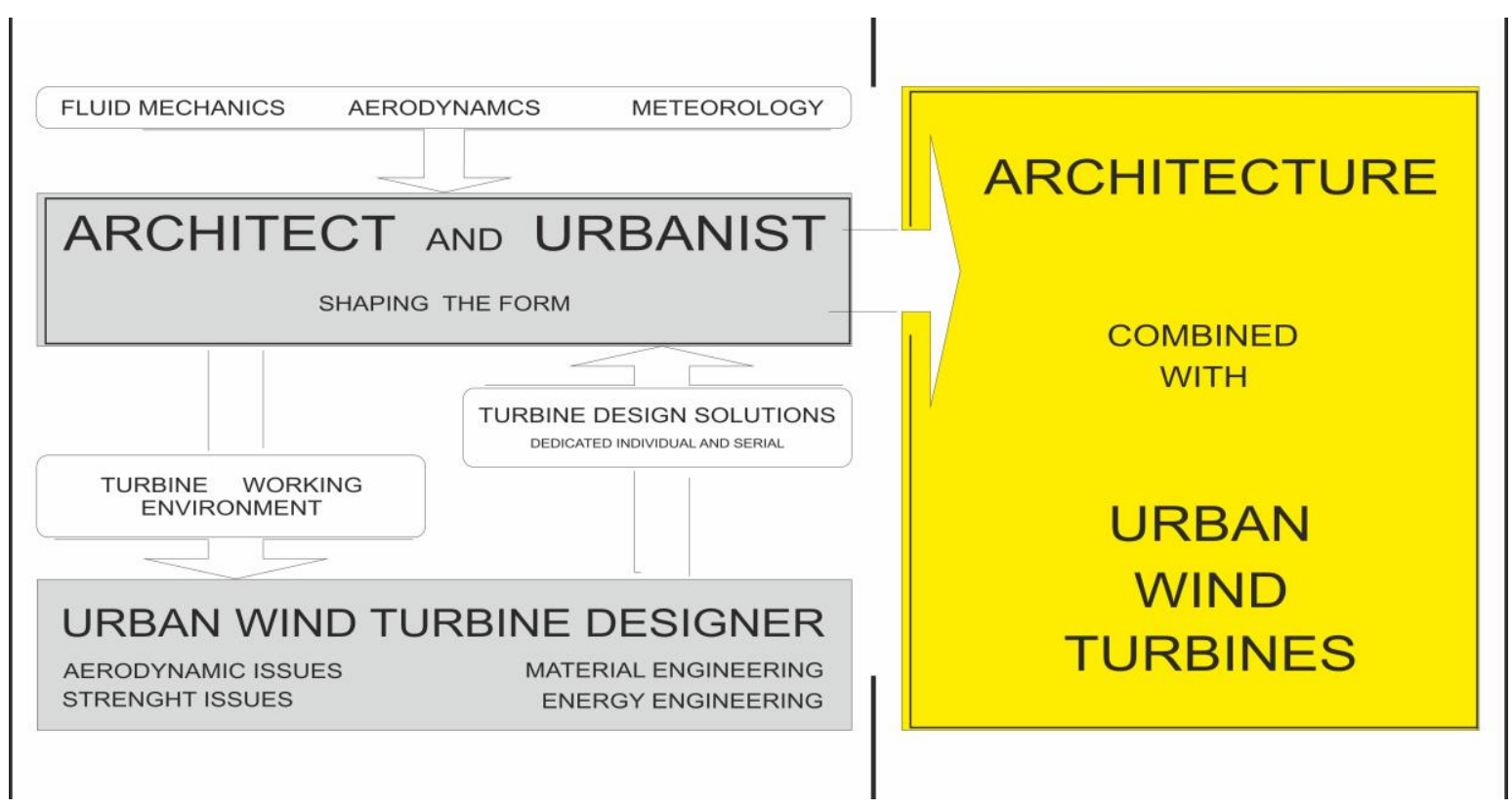

Fig. 6. Diagram of the participation of industries in the design process. Source: author

Ryc. 6. Diagram partycypacji branż w procesie projektowym. Źródło: autor

\section{ZASOBY WIETRZNE W STRUKTURZE MIEJSKIEJ - ANALIZA NUMERYCZNA CFD. MOŻLIWOŚCI WYKORZYSTANIA ENERGII WIATRU NA PRZYKŁADZIE OSIEDLA SŁONECZNEGO W SZCZECINIE}

\section{WSTĘP}

Polityka pojawiających się w ostatnich latach coraz bardziej restrykcyjnych przepisów klimatycznych wprowadzanych na Świecie, a w szczególności obejmujących kraje Unii Europejskiej, kolejne progi ograniczenia emisji gazów cieplarnianych i coraz krótsze terminy na ich osiągnięcie sprawiają, że problematykę pozyskiwania energii ze źródeł odnawialnych należy uznać za istotną w miejscach gdzie do tej pory była pomijana. Zasoby wiatrowe, wykorzystywane na terenach niezurbanizowanych, w środowisku miejskim nie są brane pod uwagę, lub wykorzystywane w niewielkim stopniu. Zjawiska związane z wietrznością w mieście, kojarzone często jako powodujące dyskomfort, rzadko rozpatrywane są w kategoriach przynoszących korzyści, jako systemy korytarzy przewietrzania miasta, czy źródło energii odnawialnej. Czynniki te skłaniają do spojrzenia na wiatr jako źródło energii stale obecne w tkance miejskiej i gotowe do wykorzystania.

Z historycznego punktu widzenia sposoby przetwarzania energii wiatru można podzielić na kilka okresów wyznaczonych jakościowymi zmianami technologii. Ślady pierwszego świadomego wykorzystania wiatru do celów energetycznych znajdujemy około pięć tysięcy lat temu w regionie Morza 
Śródziemnego (Leather T. M. 2017, s.130), gdzie używano go do napędu łodzi. Konstrukcja jednostek pozwalała rozłożyć wektor siły wiatru na składową użyteczną pozwalającą kierować łódź wyznaczonym kursem i składową pasożytniczą powodującą niepożądany dryf. Kolejna zmiana, której udokumentowane ślady przetrwały do dzisiaj dokonała sią na terenach starożytnej Persji w VII w.p.n.e. (Leather T. M. 2017, s.131). Wykorzystano w niej mechanikę pochodzącą z powłoki żagla, montując go na obrotowej konstrukcji umożliwiającej pracę stacjonarną. Funkcjonowanie tak zbudowanej turbiny nie zmieniło się do czasów obecnych, a współczesne konstrukcje, z wyjątkiem nielicznych urządzeń eksperymentalnych, pracują na tej samej zasadzie. Przekształcenia jakim przez wieki ulegały konstrukcje dotyczyły głównie technologii i przynosiły znaczne zmiany ilościowe w sprawności maszyn energetycznych. Za pierwszą turbinę wiatrową skonstruowaną z wykorzystaniem reguł usystematyzowanego podejścia naukowego można uznać urządzenie Charles'a Brush'a zbudowane w 1888 roku w Cleveland, w Ohio (Ryc. 1). Generator o mocy 12 kW był w pełni zautomatyzowany, posiadał system kierowania i ochrony przed przeciążeniem wietrznym, przekładnię pośredniczącą z prądnicą, regulację prądową i baterie (Lynn P. A. 2017, s.13). Wszystkie te elementy uczestniczą w konstrukcjach współczesnych.

\subsection{Cel artykułu}

Głównym celem badań było sprawdzenie możliwości zastosowania maszyn wiatrowych w przestrzeni zabudowanej.

\subsection{Przeprowadzone badania}

Obecność maszyn wiatrowych będących w przeszłości częstym elementem systemu osiedleńczego generuje potrzebę analizy możliwości i celowości ich współczesnego wykorzystania. Aspekt energetyczny, jako oczywisty i przyjmowany intuicyjnie, w strukturze urbanistycznej staje się niejedynym. Aerodynamika osiedla mieszkaniowego jako obszaru przyjętego do badania rozpatrywana jest również pod kątem komfortu użytkowników, a silny wiatr uznawany jest za zjawisko niepożądane. Rozpatrywane w tym kontekście instalacje małych turbin wiatrowych, przejmując część energii wiatru, stają się nie tylko urządzeniami wytwarzającymi energię elektryczną ale również, świadomie projektowane, mogą służyć kontroli i kształtowaniu warunków mezoklimatycznych. Z punktu widzenia mechaniki płynów instalacja wiatrowa, w pewnym uproszczeniu, traktowana może być jak struktura porowata spowalniająca przepływ, a odpowiednio zlokalizowana, podobnie jak zadrzewienie wpływa na lokalne warunki wietrzne. $Z$ drugiej strony duże wymagania turbin co do środowiska pracy wiążą się z koniecznością wysokiej specjalizacji procesu projektowego i znajomością zjawisk aerodynamicznych zachodzących w środowisku miejskim.

Warunki wiatrowe w strefie zabudowanej w sposób diametralny odbiegają od panujących na otwartej przestrzeni. Z powodu przeszkód terenowych wyróżniają się dużym zróżnicowaniem prędkości wiatru i występowaniem licznych przepływów turbulentnych. Turbiny pracujące $w$ instalacjach spełnić muszą szereg rygorystycznych warunków, w szczególności charakteryzować się niskimi prędkościami: startową i dla mocy nominalnej, posiadać niewielki czas reakcji oraz dużą odporność zmęczeniowa. Najczęściej spotykanym kryterium podziału generatorów wiatrowych stosowanych w obszarach zurbanizowanych jest położenie osi obrotu wirnika, zgodnie z którym rozróżniamy dwa rodzaje urządzeń:

- z poziomą osią obrotu - (HAWT - ang. Horizontal Axis Wind Turbines),

- z pionową osią obrotu - (VAWT - ang. Vertical Axis Wind Turbines).

Podział ten, mimo oczywistych zalet nie oddaje całości problematyki i jest zbyt ograniczony do oceny przydatności urządzeń pracujących w środowisku miejskim. Bardziej adekwatna jest wprowadzona przez Abohela'e typizacja określająca stopień integracji urządzenia wiatrowego z zabudową, czy lokalnym układem przestrzennym (Abohela I. 2012, s.83-94) Według klasyfikacji tej wyróżniamy cztery układy:

- BIWT (ang. building integrated wind turbines) - wolnostojące turbiny wiatrowe pracujące w pobliżu budynków i wykorzystujące wzrost prędkości przepływu wiatru spowodowany otaczającą zabudową. Montowane często w już istniejącej zabudowie lub włączane do nowych pro- 
jektów obszarów miejskich. Ten rodzaj integracji w środowisku zabudowanym jest zwykle wdrażany tam, gdzie dostępne są tereny otwarte, np. place, boiska.

- BMWT (ang. building mounted wind turbines) - konstrukcje bezpośrednio montowane na budynku będącym dla nich podstawą i służącym do zwiększenia energii wiatru trafiającego do turbiny. Wykorzystuje się je zarówno w projektach systemów wiatrowych na budynkach istniejących jak i nowo budowanych, najczęściej instalując na dachu, rzadziej na krawędziach. Tak realizowane integracje nie wpływają na rozkład funkcjonalny budynku.

- BAWT (ang. building augmented wind turbines) - ten rodzaj integracji podporządkowuje architekturę budynku maksymalizacji wydajności instalacji wiatrowej. Aerodynamiczny kształt budowli służy do dostarczania skoncentrowanej energii wiatru do napędzania turbiny. W tego typu projektach architekt odgrywa główną rolę w kształtowaniu bryły budynku w oparciu o aspekty związane $z$ aerodynamiką. Wymaga się od niego wszechstronnej wiedzy w zakresie systemów koncentracji i konwersji energii wiatru. Realizacje zgodne z tym podejściem należą do szczególnie efektownych. Najbardziej znane to: Strata SE1 (Ryc. 2) w Londynie, Bahrain World Trade Center, czy Pearl River Tower w Chinach.

- DWT (ang. ducted wind turbines) - rodzaj turbin zabudowanych, pracujących w specjalnie zaprojektowanym kanale. Stosowane tam, gdzie mamy do czynienia z dużą różnicą ciśnień w miejscach zakończeń kanału. Istotną rolę odgrywają kształt wlotu i wylotu, oraz spojlery pomagające skoncentrować energię uzyskiwaną z wiatru. W przypadku zbyt dużych prędkości przepływu wewnątrz kanału uruchamiane są przesłony chroniące turbinę przed uszkodzeniem. Instalacje te, poza konwersją energii, mogą być stosowane do wspomagania systemu wentylacji budynku.

Interpretacja warunków wietrznych w oderwaniu od wymienionych podejść projektowych prowadzi do błędnych wniosków i jest przyczyną często spotykanych niepowodzeń podejmowanych przedsięwzięć. Efektywne wykorzystanie energii wiatru w środowisku zurbanizowanym wiąże się z koniecznością uwzględnienia wielu czynników niewystępujących w terenach otwartych dla turbin pracujących w swobodnym strumieniu powietrza.

\section{WYBÓR OBSZARU BADAŃ, METODYKA}

Wybór obiektu ograniczono do zabudowy szczecińskiej. W pierwszej fazie wybrano osiem zespotów o cechach sprzyjających występowaniu użytecznych zjawisk wiatrowych. Następnie z pośród tej grupy wytypowano obiekt do analizy numerycznej.

Analiza struktury geometrycznej układu urbanistycznego pod kątem występowania korzystnych warunków dla instalacji wiatrowych wskazała na osiedla mieszkaniowe o wysokiej zabudowie. Sa to zespoły mieszkaniowe złożone najczęściej z budynków wysokich, XI - XIII. kondygnacyjnych i uzupełniających ich układ urbanistyczny budynków o wysokości IV - V. kondygnacji. Osiedla te, wykonane w technologii wielkopłytowej, budowane były na terenie Szczecina w latach 70, 80 i 90 ubiegłego wieku. Z problematyką dużej wietrzności, rozpatrywaną w niniejszym opracowaniu jako zjawisko mogące w pewnych warunkach przynosić korzyści, borykano się od początków powstawania i zasiedlania omawianych osiedli. Autorzy opracowań zwracają uwagę na niepożądane zjawiska związane z lokalnym mikroklimatem jak uciążliwe przeciągi między budynkami (Wojtkun G., 2014, s.80), bardzo silne wiatry, czy zawirowania określane przez mieszkańców jako „trąby powietrzne" (Wojtkun G. 2014, s.105). Wstępna selekcja wyłoniła osiem szczecińskich osiedli o podobnych uwarunkowaniach przestrzennych, stratyfikacji wysokościowej i technologii w jakiej powstały. Osiedla Arkońskie, Bandurskiego, Bukowe, Kaliny, Książąt Pomorskich, Majowe, Słoneczne i Zawadzkiego pomimo wspólnych cech morfologii zabudowy takich jak wysokość, kubatura obiektów i ich proporcje, wykazują znaczne różnice w charakterystyce aerodynamicznej wynikające w głównej mierze z układu przestrzennego zabudowy, jej orientacji w terenie, ilości i rozkładu stref otwartych wewnątrz rozpatrywanych założeń. Odległości pomiędzy poszczególnymi jednostkami i kąty jakie tworzą płaszczyzny ich elewacji w określonych miejscach sprzyjają lokalnym przyspieszeniom przepływów mas powietrza, natomiast w innych tworzą martwe strefy, wolne od wiatru. 
Wymienione osiedla poddano ocenie pod kątem cech warunkujących występowanie zjawisk aerodynamicznych mogących być rozpatrywanymi jako sprzyjające, bądź wykluczające funkcjonowanie mikroinstalacji wiatrowych $w$ środowisku zespołu mieszkaniowego. $Z$ drugiej zaś strony przedmiotem zainteresowania była możliwość ograniczania zjawisk niekorzystnych takich jak nadmierne lokalne przyspieszenia mas powietrza, uderzenia wiatru wynikające z występujących turbulencji, mogące być niwelowane za pomocą instalacji wiatrowych przejmujących energię kinetyczną wiatru i powodując tłumienie przepływów w miejscach krytycznych.

Wprowadzone kryteria oceny zakładają podział na układ globalny (makro), jakim jest całe osiedle i lokalny (mikro), gdzie brane są pod uwagę poszczególne elementy takie jak budynki i wzajemne ich relacje, przewężenia, przesłonięcia, otwory itp. W podejściu globalnym szacowano wpływ zróżnicowania wysokości i planu osiedla na ogólną charakterystykę aerodynamiczna warunkującą możliwość swobodnego przepływu powietrza, gdzie struktury równoległe jak długie ulice o stosunkowo zwartej zabudowie umożliwiają lokalnym wiatrom płynny ruch (układ „przepuszczalny” dla wiatru). Zakłócają go zamknięte układy zabudowy („nieprzepuszczalne” dla wiatru), tworzące wielokąty lub zamknięte pętle (...) powodują zatrzymanie i zawirowania powietrza (Zielonko-Jung K. 2013, s.45). Rozpatrując zjawiska działające lokalnie wyodrębniono kilka schematów opisujących zachowanie się wiatru w środowisku miejskim w zależności od geometrii zabudowy $\mathrm{i}$ jej wzajemnych relacji (Flaga A. 2008, s.333). Wyróżniono tutaj: efekt wydłużonego budynku (ang. bar effect) - ze zjawiskiem mamy do czynienia w przypadku budynków średnio wysokich o długości co najmniej ośmiokrotnie większej od wysokości . Zjawisko powstaje kiedy kierunek wiatru tworzy z osią budynku kąt zbliżony do $45^{\circ}$. Powoduje to, że większość opływających budynek mas powietrza przepływa nad nim i opada po stronie zawietrznej powodując wzrost prędkości strugi i liczne zawirowania. Efekt przewężenia przepływu (ang. Venturi effect) - powstaje w przypadku dwóch budynków, których płaszczyzny ścian tworzą ze sobą kąt ostry, a kierunek wiatru zbliżony jest do dwusiecznej tego kąta. Wysokość płaszczyzn musi odpowiadać co najmniej wysokości pięciu pięter, a suma ich długości być nie mniejsza niż $100 \mathrm{~m}$. Zjawisko powstaje gdy szerokość wylotu jest dwa do trzech razy mniejsza od wlotu i charakteryzuje się znacznymi przyspieszeniami wiatru w strefie wylotowej. Efekt otworu (ang. gap effect) - zjawisko charakterystyczne dla osiedli mieszkaniowych, gdzie długi budynek koliduje z ciągiem komunikacyjnym, dla którego w kondygnacji parteru powstaje pasaż komunikacyjny, brama lub budynek wspiera się na słupach. Przy wietrze prostopadłym do elewacji i wysokości budynku wynoszącej pięć i więcej kondygnacji w pasie otworu dochodzi do znacznych przyspieszeń mas powietrza wywołanych dużą różnicą ciśnień pomiędzy stroną nawietrzną i zawietrzną budynku, a wraz z rosnącą wysokością budynku efekt się nasila. Zjawisko jest dość powszechne i odbierane jako niekorzystne ze względu na dyskomfort mieszkańców. Efekt naroża (ang. corner effect) - związany jest z powstawaniem różnicy ciśnień wokół naroży budynków, wynikających z parcia mas powietrza od strony nawietrznej i ssania od strony zawietrznej w wyniku czego powstaje strefa o podwyższonej prędkości wiatru. Zaburzenie jest ściśle związane z wysokością budynku. Znaczącą rolę zaczyna odgrywać przy budynkach powyżej pięciu kondygnacji, a szczególny problemem staje się dla budynków wysokościowych. Efekt zawirowań w śladzie aerodynamicznym - linie wiatru po spotkaniu z budynkiem łączą się dopiero w pewnej odległości za nim tworząc po stronie zawietrznej strefę cienia aerodynamicznego o obniżonym ciśnieniu statycznym. Ze względu na występujące różnice ciśnień zjawisko to może być rozpatrywane jako szczególnie korzystne dla instalacji wiatrowych zintegrowanych z budynkiem. Efekt wąskiego kanału (ang. channel effect) - nazywany niekiedy efektem zassania, pojawia się w przypadku układów równoległych, np. ulica ze zwartymi ciągami zabudowy po obu jej stronach i wysokości budynków trzykrotnie większej niż szerokość ulicy. Układ tworzy kanał dla strumienia powietrza, a anomalie tworzy w połączeniu z np. silnymi turbulencjami. Efekt spływającego wiru (ang. downwash vortex effect) - tworzy się w przypadku budynków o znacznej różnicy wysokości, sąsiadujących ze sobą w niewielkiej odległości, przybliżonej do wysokości niższego z budynków. Osie budynków są wzajemnie równoległe, a kierunek wiatru do nich prostopadły. Za nawietrznym, niższym budynkiem tworzy się obszar zawirowań przepływającego powietrza, a w strefach naroży budynku wysokiego dochodzi do wyraźnych wzrostów prędkości wiatru. Efekt zasłonięcia (ang. shetler effect), zwany też efektem schronu - polega na odwróceniu układu występującego w przypadku efektu spływającego wiru, przeszkoda o większej wysokości znajduje się po stronie nawietrznej. Obiekt niższy pozostaje w cieniu aerodynamicznym wyższego w strefie zawirowań i ob- 
niżonego ciśnienia. Z sytuacją taka mamy do czynienia w przypadku przesłaniania przez wysokie budynki, ekrany drogowe, pasy zieleni. Wymienione schematy aerodynamiczne, występując jednocześnie, mogą tworzyć złożone zależności , zwielokrotniając lub niwelując się wzajemnie.

Dokonując selekcji pomiędzy osiedlami wzięto pod uwagę, poza występowaniem warunków potencjalnie korzystnych dla instalacji wiatrowych, zróżnicowanie aerodynamiczne i przestrzenne zabudowy dające możliwość wykazania złożoności i korelacji między opisanymi zjawiskami aerodynamicznymi. Do analizy numerycznej (ang. computational fluid dynamics - CFD) wybrano zabudowę osiedla Słonecznego w Szczecinie (Ryc. 3). Jest to osiedle o największym potencjale wietrznym. Zróżnicowanie wysokościowe i plan zabudowy wskazują na możliwość wystąpienia licznych przyspieszeń i spiętrzeń linii wiatru. W zabudowie dominują: od strony zachodniej - nawietrznej układ centralny, składający się z trzech budynków wysokich, trzynastokondygnacyjnych na planie gwiazdy trójramiennej, otoczonych prawie domkniętym okręgiem tworzonym przez budynki pięciokondygnacyjne, oraz układ liniowy, tworzony przez dwa budynki trzynastokondygnacyjne od strony zawietrznej. Wysoka zabudowa z wolnymi przestrzeniami generuje bardzo zróżnicowane przepływy. Liczne cienie aerodynamiczne tworzące duże różnice ciśnień i występowanie przewężek powoduje lokalne wzrosty prędkości przepływów, użyteczne ze względu na możliwość wykorzystania wiatrowych źródeł energii.

Mapę lokalnych warunków wiatrowych osiedla wykonano przy użyciu modelowania CFD, zaliczanego do metod obliczeniowej inżynierii wiatrowej. Symulacja warunków w modelu zabudowy przedstawia fluktuacje prędkości mas powietrza, oraz wyodrębniony na kolejnej mapie składnik pionowy prędkości wiatru $V z$. Jakościowa ocena przepływu pozwala na wskazanie obszarów przyspieszeń, spiętrzeń i stagnacji, na podstawie których można szacować występowanie stref potencjalnie korzystnych dla lokalizacji instalacji wiatrowych.

\section{BADANIA PRZEPŁYWU POWIETRZA}

Przeprowadzone badanie ma charakter jakościowy. Jego celem było wskazanie miejsc o zwiększonych wartościach prędkości przepływu powietrza, oraz obszarów stagnacji (stref ciszy). Przyjęto najczęściej występujący kierunek wiatru dla danego terenu. Wartości oznaczono jako względne w stosunku do średniej prędkości wiatru na badanym obszarze i przedstawiono w skali procentowej. W morfologii zabudowy wyróżniono trzy grupy obiektów charakteryzujących się spójnością cech istotnych dla generowania charakterystycznych zjawisk aerodynamicznych. Są to: grupa I trzech budynków wysokich - trzynastokondygnacyjnych na planie gwiazdy równoramiennej, II zespół dwóch równoległych budynków trzynastokondygnacyjnych, o nieco przesuniętych osiach, tworzących ścianę o długości 390 metrów z przerwą w środkowej części i zespół III, na który składają się budynki średniej wysokości, pięciokondygnacyjne, tworzące na rzucie wycinki okręgów. Obszary jakie poddano ocenie spełniać musiały kryteria technicznej możliwości montażu instalacji generatorów wiatrowych $\mathrm{w}$ istniejącej zabudowie oraz występowania korzystnych warunków wietrznych (Ryc. 4).

Ogólne zależności jakie zaobserwowano dla całego zespołu zabudowy, to spadek prędkości mas powietrza wewnątrz modelowanego układu połączony z jej wzrostem w punktach skrajnych; wzrost prędkości wiatru wraz ze wzrostem wysokości nad poziomem terenu; oraz większa skłonność do zmian kierunku ruchów powietrza w warstwach niskich. Największe zróżnicowanie warunków wietrznych występuje w najniższym badanym przekroju, na wysokości 5 metrów powyżej terenu. Oznaczono na niej pięć stref wzmożonego przepływu i trzy obszary silnych turbulencji. W kształtowaniu przepływu na tej wysokości duża rolę odgrywają budynki zespołu III. Napływające powietrze, w zależności od kąta tworzonego $w$ danym miejscu $z$ fasadą biegnącą po okręgu spiętrza się przed budynkiem, tworząc za nim efekt spływającego wiru, bądź opływa go tworząc efekt wydłużonej bariery. Przewężenia tworzone przez budynki zespołów II i III odpowiadają za powstawanie efektu Venturi'ego i gwałtowne przyspieszenia wiatru. Zespoły I i III tworzą dwie strefy lokalnych przyspieszeń, a ze względu na nieregularny plan zabudowy, generowane przez nie zjawiska wykazują dużą złożoność. Budynki zespołu II o łącznej długości 390 i wysokości 35 metrów, tworzą dla napływającego powietrza zwartą, prawie prostopadłą $\left(81^{\circ}\right)$ przeszkodę. Niewielka przerwa pomiędzy budyn- 
kami jest miejscem silnego przyspieszenia mas powietrza na skutek różnicy ciśnień przed i za przeszkodą. Oznaczona tam strefa akceleracji strugi, ze względu na złożoność geometrii (mimośrodowe przesunięcie osi budynków) i intensywność występujących zjawisk aerodynamicznych, posiada największy potencjał energetyczny dla instalacji wiatrowych na danym terenie. W przypadku wyższych partii budynków trzynastokondygnacyjnych zespołu I i II, w obszarach krawędzi ich ścian i dachów symulacja wykazała lokalne przyspieszenia powodowane efektem naroża. Tam też oznaczono strefy dla odnawialnych źródeł energii (OZE) (Ryc. 5).

Istotnym aspektem badania było wydzielenie składowej pionowej $z$ wektora prędkości mas powietrza $(V z)$, zobrazowane na planszach. Element ten w warunkach zurbanizowanych odgrywa znaczącą rolę, a pomijanie go prowadzi do licznych niepowodzeń w realizowanych instalacjach. Strefy wzmożonych ruchów pionowych zaobserwować można głównie w obszarach przyściennych budynków oraz w znacznej odległości za zespołem II. Spowodowane jest to spiętrzaniem linii wiatru przez całe założenie i zasysaniem go przez obszar obniżonego ciśnienia za osiedlem - efekt zawirowań w cieniu aerodynamicznym. Podobną sytuację obserwujemy, w mniejszej skali, analizując oddzielnie poszczególne budynki. W przypadku zabudowy wysokiej, trzynastokondygnacyjnej powietrze spotykające na swej drodze budynek, do około jednej trzeciej jego wysokości przyjmuje ujemną wartość Vz, tworząc w niskich partiach zabudowy strefy recyrkulacji, natomiast powyżej tej wysokości kieruje się ku górze uzyskując w partiach szczytowych największą prędkość pionową, mającą znaczny udział w kształtowaniu charakterystyki aerodynamicznej dachu. Zasięg odziaływania ruchów pionowych przyjmować należy jako znaczny. Obrazują to ślady oddziaływania zespołu III w warstwie 5D, której wysokość nad poziomem terenu ponad dwukrotnie przekracza wysokość zabudowy powodującej zjawisko. Wyodrębnienie i analizę komponentu Vz uznać należy za warunek konieczny przy ocenie wietrzności badanego układu, uświadamia bowiem jak istotnym elementem w obszarze zurbanizowanym jest składowa pionowa.

Analizy i opis zjawisk wietrznych na osiedlu Słoneczne w Szczecinie, sporządzone metodami analitycznymi, przedstawione zostały w monografii Osiedle mieszkaniowe w strukturze miasta XX wieku przez G. Wojtkuna (Wojtkun G. 2014, s.76). Modelowanie numeryczne potwierdziło w całości wyżej wymienione badania, oraz uzupełniło o element wertykalny.

\section{DYSKUSJA}

Warunki wiatrowe $\mathrm{w}$ środowisku zabudowanym różnią się znacznie od warunków w miejscach o niezakłóconym przepływie, takich jak teren otwarty, gdzie rozkład wiatru uznać można za niemal dwuwymiarowy. Turbulentny charakter pola wiatru występujący na obszarach zurbanizowanych wprowadza element pionowy, jako trzecią składową jego prędkości, oddziałującą na instalację wiatrową pracującą w warunkach miejskich (Anup K. C. I in. 2018, s.5). Obok złożoności zjawisk wiatrowych wskazywana jest ich nieprzewidywalność i stochastyczny charakter nie dający opisać się żadnym znanym rozkładem statystycznym (Zielonko-Jung K. 2013, s. 60), a także niewystarczająca ilość szczegółowych badań i pomiarów w terenie, które pomogły by scharakteryzować wiatr miejski i zrozumieć jego wpływ na turbiny (Anup K. C. I in. 2018, s.6). Pomimo tych przeszkód autorzy wykazują szereg korzyści wynikających ze stosowania miejskich instalacji wiatrowych, w tym również tych wybiegających poza konwersję energii wiatru i obejmują szereg zagadnień dotyczących poprawy jakości funkcjonowania obszaru. Do najważniejszych zaliczyć można:

- Zmianę charakterystyki wietrznej przestrzeni w kierunku uspokojenia, spowolnienia występujących przeciągów i porywów wiatru. Turbina wiatrowa jest elementem turbulizującym i obniżającym energię strumienia powietrza przez nią przechodzącego. Moc użyteczna wytwarzana w silniku wiatrowym, przejęta od strumienia powietrza, wynika z różnicy energii kinetycznej powietrza przed i za wirnikiem. Jest to szczególnie korzystne, w miejscach gdzie wcześniej występowały kłopoty ze zbyt dużą aktywnością wiatru.

- Wykorzystanie instalacji wiatrowych do integracji z systemami wspomagającymi użytkowanie budynków, w szczególności wykorzystanie wiatru do naturalnego wentylowania (Zielonko-Jung K. 2013, s.72). 
- Przy zwiększającej się zdolności wykorzystania zasobów wiatrowych w obszarach miejskich małe turbiny wiatrowe (SWT - ang. small wind turbine) przeznaczone do pracy w środowisku zurbanizowanym oraz turbiny zintegrowane z budynkami stanowią wartość dla architektów I projektantów ze względu na zerowy współczynnik nakładu nieodnawialnej energii pierwotnej w obliczeniach charakterystyki energetycznej budynków, dając większą swobodę w projektowaniu instalacji.

- Zespoły wiatrowych OZE są doskonałym narzędziem dostarczającym olbrzymich ilości danych na temat aktualnie panujących warunków, przydatnych do tworzenia map pogodowych, prognoz, zarządzania systemami „inteligentnego miasta”.

- Dywersyfikacja źródeł energii, rozproszenie systemu energetycznego, pomijanie strat na przesyle.

- Niewielki czas wdrożenia instalacji wiatrowych (Leather T. M. 2017, s.8).

- Aspekt społeczny, wskazywany obecnie jako szczególnie istotny, niosący ze sobą korzyści wizerunkowe dla regionu, społeczności lokalnej, jednostki. Budynki proekologiczne mają wpływ na postrzeganie; nowoczesny obiekt architektoniczny staje się znakiem miejsca wykorzystując (...) najnowsze technologie (Czekiel-Świtalska E. 2008, s.1), pozytywnym identyfikatorem w skali osiedla, dzielnicy, miasta.

W kontekście spodziewanych zysków, spełnienie wysoko postawionych wymogów można uznać za uzasadnione. Przyjmując jednocześnie skomplikowane warunki konieczne do spełnienia podczas projektowania instalacji miejskich turbin wiatrowych (UWT - ang. urban wind turbine) (Anup K. C. I in. 2018, s.2). Stojąc bowiem, wobec problemów środowiskowych z jakimi się obecnie borykamy trzeba mieć świadomość, że problem wykorzystania wiatru w środowisku miejskim będzie musiał być podjęty, i że jest to tendencja przyszłościowa, wymagająca rozwijania (Zielonko-Jung K. 2013, s. 77-78).

\section{WNIOSKI}

Zastosowanie turbin wiatrowych w środowisku zurbanizowanym wymaga zrozumienia warunków wietrznych i zjawisk aerodynamicznych w nim zachodzących. Niepowodzenia prób wykorzystania energii wiatru wynikają z tego, że instalowane są urządzenia do tego nieprzystosowane. Miejskie turbiny wiatrowe pracują $w$ diametralnie odmiennych warunkach od ich komercyjnych odpowiedników na otwartej przestrzeni, czy morzu, a ich podobieństwo jest pozorne. Przepływy formowane przez przeszkody terenowe mają bardzo złożoną dynamikę, przez co należy w sposób szczególny traktować kształtowanie formy najbliższego otoczenia turbiny. Złożoność zagadnień projektowych pociąga za sobą konieczność współpracy projektantów z różnych specjalizacji.

Diagram opisuje schemat współpracy branż projektowych i określa dziedziny należące do obszaru ich działań (Ryc. 6). Obok architekta/urbanisty, określającego główne założenia projektowe i warunki w jakich będzie pracowała instalacja, istotną rolę odgrywają specjaliści z zakresu budowy i eksploatacji maszyn, inżynierii materiałowej, zagadnień zmęczeniowo-wytrzymałościowych, energetyki i automatyki oraz aerodynamiki. Ich współpraca powinna odbywać się we wszystkich fazach projektu.

Kolejnym problemem jest wskazanie w zabudowie miejsc korzystnych pod względem wietrzności dla turbin. W badanym modelu jest to zaledwie $5,5 \%$ powierzchni jego rzutu. Fakt ten obrazuje jak istotna jest analiza przepływów w układzie i jak łatwo popełnić błąd w wyznaczeniu lokalizacji dla generatorów. Wobec powyższych, analizę numeryczną przepływów należy uznać za wymóg minimalny we wstępnej fazie projektowej. Podejście takie pozwoli uniknąć błędów i wykorzystać układ zabudowy nie jako przeszkodę, lecz element kształtujący linie wiatru w sposób korzystny dla instalacji. Zapewniając optymalne warunki pracy i gwarantując maksymalną wydajność. 


\section{BIBLIOGRAPHY}

Abohela I. Effect of Roof Shape, Wind Direction, Building Height and Urban Configuration on the Energy Yield and Positioning of Roof Mounted Wind Turbines, (2012), School of Architecture, Plan-ning and Landscape, Newcastle University 2012

Anup K. C., Whale J., Urmee T., (2018), Urban wind conditions and small wind turbines in the built environment: A review, Pages 268-283 in Renewable Energy 131, February 2019, Elsevier.

Czekiel-Świtalska E., Znak miejsca a nowoczesna przestrzeń architektoniczna, (2008) Wydaw-nictwo Politechniki Krakowskiej, 2008.

Flaga A., Inżynieria wiatrowa, podstawy i zastosowania, (2008), Wydawnictwo „Arkady”, Warszawa 2008, ISBN 978-83-213-4526-0

Letcher T. M., Wind Energy Engineering, (2017) Elsevier, London 2017, ISBN: 978-0-12-809451-8

Lynn P. A., Onshore and Offshore Wind Energy An Introduction, (2017) A John Wiley \& Sons, Ltd., Publication, Hong Kong 2017, ISBN: 978-04-709-7608-1

Renewable Energy. https://www.renewableenergylawinsider.com/2011/07/28/origins-of-wind-power-mrbrushs-windmill-dynamo/, access: 12.02 .2021

Wikimedia Commons. https://commons.wikimedia.org/wiki/File:Strata_SE1_from_Monument_2014.jpg, access: 12.02 .2021

Wojtkun G., (2014), Osiedle mieszkaniowe w strukturze miasta XX wieku, Wydawnictwo Uczelniane Politechniki Szczecińskiej, Szczecin 2004, ISBN 83-88764-48-9

Zielonko-Jung K., Kształtowanie przestrzenne architektury ekologicznej w strukturze miasta, (2013) Oficyna wydawnicza Politechniki Warszawskiej, Warszawa 2013, ISSN 1896-1630

\section{AUTHOR'S NOTE}

The author is a student of architecture and a graduate of postgraduate studies in real estate appraisal. His research interests include the issues of solar and wind renewable energy sources in buildings and in the urban structure.

\section{O AUTORZE}

Autor jest studentem kierunku architektura oraz absolwentem studiów podyplomowych w zakresie szacowania nieruchomości. W obszarze jego zainteresowań badawczych znajduje się problematyka solarnych i wiatrowych odnawialnych źródeł energii w budowli oraz w strukturze miejskiej.

Contact | Kontakt: rafal obuchowicz@zut.edu.pl 